\title{
Cytotoxicities of Sodium Benzoate in Primary Culture of Hepatocytes from Adult Rat Liver
}

\author{
Kazuhiko Oyanagi, Yoshinori Kuniya, Masayoshi \\ Nagao, Akira Tsuchiyama and Tooru Nakao \\ Department of Pediatrics, Sapporo Medical College, \\ Sapporo 060
}

Oyanagi, K., Kuniya, Y., Nagao, M., Tsuchiyama, A. and Nakao, T. Cytotoxicities of Sodium Benzoate in Primary Culture of Hepatocytes from Adult Rat Liver. Tohoku J. exp. Med., 1987, 152 (1), 47-51 — The cytotoxicities of sodium benzoate was studied using primary culture of hepatocytes established from adult rat liver by a collagenase perfusion technique and maintained as a monolayer in serum-free culture medium. The activities of ornithine transcarbamylase (as a marker of mitochondria) and tyrosine aminotransferase (as a marker of cytosol) were clearly suppressed by sodium benzoate at concentration in excess of $500 \mu \mathrm{g} /$ $\mathrm{ml}$. Intracellular protein synthesis and DNA synthesis were also suppressed, and the suppression of DNA synthesis was observed even with a lower concentration of benzoate $(100 \mu \mathrm{g} / \mathrm{ml})$.— cytotoxicity ; sodium benzoate ; hyperammonemia ; cultured hepatocytes

Since the report by Batshaw et al. (1981), sodium benzoate (BA-Na) therapy has been used on many children with congenital hyperammonemia. At present, $200-500 \mu \mathrm{g} / \mathrm{ml}$ is thought to represent the clinically effective and safe concentration in blood (Green 1981). No report on functional disturbance of the liver due to BA-Na has been reported. An influence of BA-Na on mitochondrial enzymes, however, has been reported (Gatley and Sherratt 1977). In the present study, the hepatic toxicity of $\mathrm{BA}-\mathrm{Na}$ was evaluated in vitro using primary culture of hepatocytes.

\section{Materials and Methods}

The primary culture of hepatocytes from adult rats was prepared according the method of Tanaka et al. (1978). The liver of a male Wistar rat of approximately $200 \mathrm{~g}$ of body weight was perfused with collagenase in situ to separate the hepatocytes. The cells were seeded in a plastic culture dish at a concentration of $5 \times 10^{4} \mathrm{cells} / \mathrm{cm}^{2}$ and cultured in Williams medium E containing $5 \%$ fetal calf serum, $10^{-9} \mathrm{M}$ dexamethasone and $10^{-9} \mathrm{M}$ insulin. When a monolayer of cell sheet was formed in 3-4 hr after seeding, the medium was changed to serum-free medium containing $10^{-9} \mathrm{M}$ dexamethasone and $5 \mathrm{U} / \mathrm{ml}$ of aprotinin. The culture medium was changed daily. On the third day of culture, it was replased with one of sets of medium containing BA-Na of 7 different concentrations ranging

Received January 16, 1987; accepted for publication March 12, 1987. 
0 to $1 \times 10^{4} \mu \mathrm{g} / \mathrm{ml}$. In order to evaluate the biochemical, ornithine transcarbamylase (OTC) as a marker of mitochondrial fraction and tyrosine aminotransferase (TAT) as a marker of cytosolic fraction were measured by Schimke's (1962) and Granner's and Tomkins (1970) methods, respectively.

Measurement of DNA synthesis. $48 \mathrm{hr}$ after initiation of the culture, the medium was replased with Williams medium E containing a range concentration of BA-Na (serum-free, with addition of $10^{-9} \mathrm{M}$ insulin, $10^{-9} \mathrm{M}$ dexamethasone, and $5 \mathrm{U} / \mathrm{ml}$ of aprotinin) and culture was continued for another $24 \mathrm{hr}$.

At the end of $24 \mathrm{hr}$ of culture, $\left[{ }^{3} \mathrm{H}\right]$ thymidine $(2.5 \mu \mathrm{Ci} / \mathrm{ml}, 0.3 \mu \mathrm{Ci} / \mathrm{mole})$ was added and the mixture was incubated for $4 \mathrm{hr}$. The cells were washed twice cold PBS and treated with $10 \%$ trichloroacetic acid (TCA) for $2 \mathrm{hr}$ at $4^{\circ} \mathrm{C}$, followed by digestion with $0.5 \mathrm{~N} \mathrm{NaOH}$ at $37^{\circ} \mathrm{C}$ for $1 \mathrm{hr}$. After washing twice with $5 \% \mathrm{TCA}$, the sample was heated at $90^{\circ} \mathrm{C}$ for $15 \mathrm{~min}$ and the radioactivity of the TCA-soluble fraction was measured using a Beckman liquid scintilation counter.

Assay of intra- and extracellular protein synthesis. After $24 \mathrm{hr}$ of incubation of the cultured liver cells in Williams $\mathrm{E}$ containing various concentrations of $\mathrm{BA}-\mathrm{Na}, \mathrm{L}-\left[\mathrm{U}-{ }^{14} \mathrm{C}\right]$ leucine $(1 \mu \mathrm{Ci} / \mathrm{ml}, 348 \mu \mathrm{Ci} /$ mole) was added and the incubation was continued for $3 \mathrm{hr}$. The cells were washed with cold PBS and treated with $10 \%$ TCA for $2 \mathrm{hr}$ at $4^{\circ} \mathrm{C}$. After digestion with $1 \mathrm{~N} \mathrm{NaOH}$ at $37^{\circ} \mathrm{C}$ for $1 \mathrm{hr}$, the cells were washed with $5 \%$ TCA twice and dissolved in $0.1 \mathrm{~N} \mathrm{NaOH}$. An aliquot was then removed and the radioactivity of this fraction was defined as the ability of protein synthesis. The ability of extracellular (secretory) protein synthesis was measured by collecting the medium with addition of L$\left\lceil\mathrm{U}-{ }^{14} \mathrm{C}\right]$ leucine and treating it with $10 \% \mathrm{TCA}$, followed by a centrifugation at $3,000 \mathrm{rpm}$ for 15 min. The precipitate was again washed with $5 \%$ TCA and dissolved in $0.1 \mathrm{~N} \mathrm{NaOH}$. An aliquot was used for the measurement of ratioactivity.

\section{RESULTS}

Time course changes of OTC and TAT activities. Figs. 1 and 2 show the time course changes of OTC and TAT activities. OTC activity tended to decrease during $3 \mathrm{hr}$ of incubation even in the medium containing $200 \mu \mathrm{g} / \mathrm{ml}$ of BA-Na. At $500 \mu \mathrm{g} / \mathrm{ml}$ of BA-Na, a marked decrease was noted after $24 \mathrm{hr}$. While TAT activity should have been induced by dexamethasone in the culture medium, it tended to be inhibited from an early period even at low BA-Na concentrations (100-200 $\mu \mathrm{g} / \mathrm{ml})$. More pronounced inhibition occured at $24 \mathrm{hr}$.

Changes of the ability of DNA synthesis. As shown in Fig. 3, the ability of DNA synthesis decreased slightly after $24 \mathrm{hr}$ even without BA-Na loading. At concentrations of BA-Na higher than $100 \mu \mathrm{g} / \mathrm{ml}$, DNA synthesis decreased to less than $50 \%$ of control. At concentrations higher than $2,500 \mu \mathrm{g} / \mathrm{ml}$, DNA synthesis could not be detected.

Ability of intra-and extracellular protein synthesis. The ability of intracellular protein synthesis decreased significantly at $500 \mu \mathrm{g} / \mathrm{ml}$ of BA-Na concentration. Regarding the ability of extracellular (secretory) protein synthesis, no significant difference from control was noted at 200 and $500 \mu \mathrm{g} / \mathrm{ml}$ of BA-Na concentrations (Table 1).

\section{Discussion}

BA-Na has been used safely at low dose for short period, as an addition to 


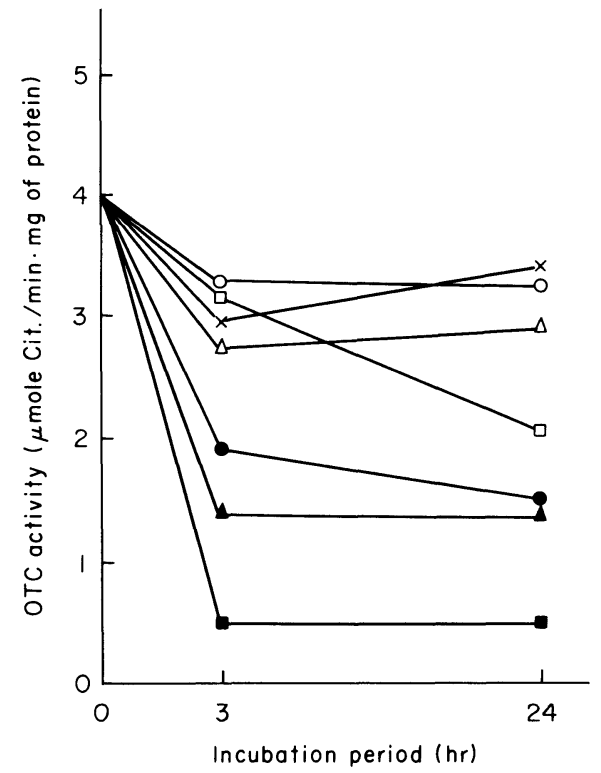

Fig. 1. Effects of sodium benzoate to OTC activity in primary culture of hepatocytes. Concentrations of benzoic acid in medium: $\bigcirc-\bigcirc$, none; $\times \longrightarrow \times, 100 \mu \mathrm{g} / \mathrm{ml} ; \triangle \longrightarrow \triangle, 200 \mu \mathrm{g} / \mathrm{ml} ; \square-\square, 500 \mu \mathrm{g} / \mathrm{ml}$; $2,500 \mu \mathrm{g} / \mathrm{ml} ; \mathbf{\Delta} \boldsymbol{- \Delta}, 5,000 \mu \mathrm{g} / \mathrm{ml} ; \mathbf{\square}, 10,000 \mu \mathrm{g} / \mathrm{ml}$.

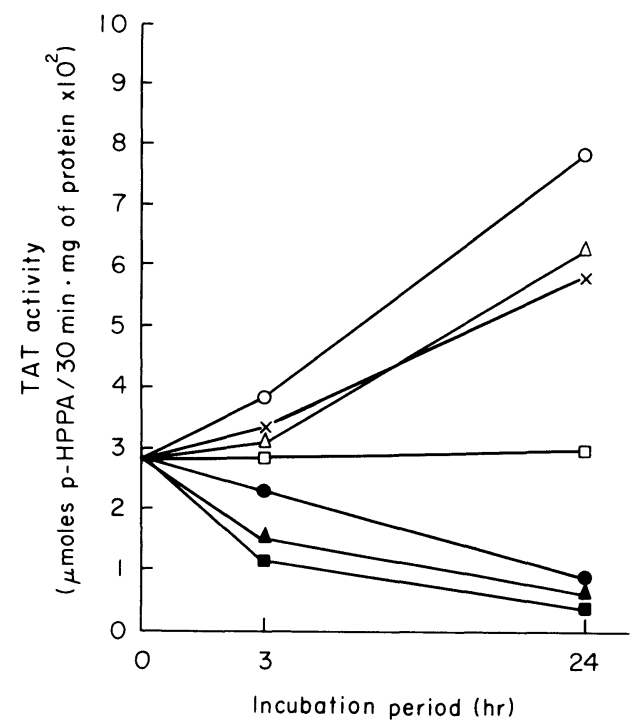

Fig. 2. Effects of sodium benzoate to TAT activity in primary culture of hepatocytes. Concentrations of benzoic acid in medium: $\bigcirc-\bigcirc$, none; $\times \longrightarrow \times, \quad 100 \mu \mathrm{g} / \mathrm{ml} ; \triangle \longrightarrow \triangle, 200 \mu \mathrm{g} / \mathrm{ml} ; \square-\square, 500 \mu \mathrm{g} / \mathrm{ml}$; $2,500 \mu \mathrm{g} / \mathrm{ml} ; \mathbf{\Delta \longrightarrow}, 5,000 \mu \mathrm{g} / \mathrm{ml} ; \mathbf{\square}, 10,000 \mu \mathrm{g} / \mathrm{ml}$. 


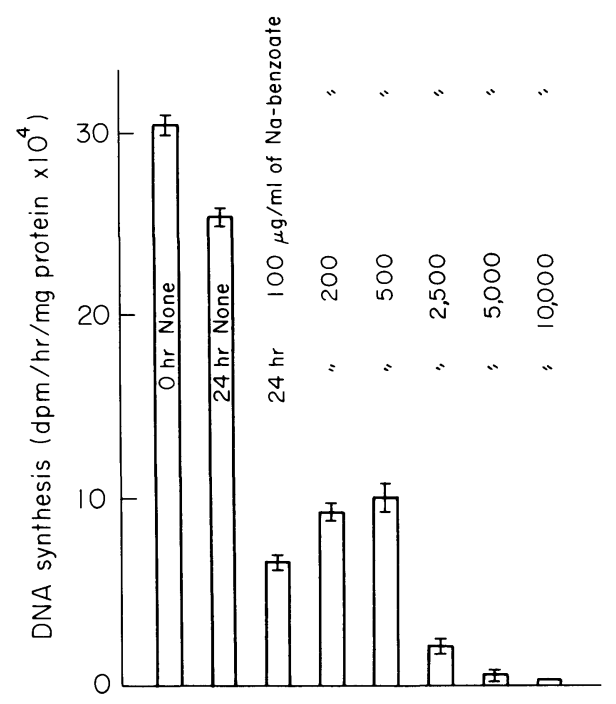

Fig. 3. Effects of sodium benzoate to DNA synthesis in primary culture of rat hepatocytes.

TABLE 1. Effects of sodium benzoate in protein synthesis

\begin{tabular}{lcc}
\hline \multicolumn{1}{c}{ Medium } & $\begin{array}{c}\text { Extracellular } \\
\text { protein synthesis } \\
(\mathrm{dpm} / \mathrm{mg} \text { protein } \\
\left.\text { per } 3 \mathrm{hr} \times 10^{4}\right)\end{array}$ & $\begin{array}{c}\text { Intrcellular } \\
\text { protein synthesis } \\
(\mathrm{dpm} / \mathrm{mg} \text { protein } \\
\left.\text { per } 3 \mathrm{hr} \times 10^{4}\right)\end{array}$ \\
\hline $\mathrm{WE}$ & $3.21 \pm 0.24$ & $1.10 \pm 0.13$ \\
$\mathrm{WE}+\mathrm{BA}-\mathrm{Na}$ & $2.84 \pm 0.36$ & $0.97 \pm 0.08$ \\
$\begin{array}{c}200 \mu \mathrm{g} / \mathrm{ml} \\
\mathrm{WE}+\mathrm{BA}-\mathrm{Na}\end{array}$ & $3.17 \pm 0.16$ & $0.27 \pm 0.03$ \\
$500 \mu \mathrm{g} / \mathrm{ml}$ & & \\
\hline
\end{tabular}

Values are means \pm s.D. for 3 experiments. WE, Williams medium $\mathrm{E} ; \mathrm{BA}-\mathrm{Na}$, Sodium benzoate.

food and drugs for antiseptic purpose, without impairing liver functions. Even in the treatment of congenital hyperammonemia requiring a relatively large dose, BA-Na administration is reported to be safe as long as the blood concentration of BA-Na does not exceed 200-500 $\mu \mathrm{g} / \mathrm{ml}$ (Green 1981). BA-Na, however, is one of the uncouplers of oxidative phosphotrylation in mitochondria. The authors therefore evaluated the cytotoxic action of BA-Na at currently used therapeutic concentrations, using cultured liver cells.

At a concentration of BA-Na in blood of $500 \mu \mathrm{g} / \mathrm{ml}$, which is thought to represent the upper limit of the clinically safe range, enzyme activities, ability of protein synthesis, and ability of DNA synthesis were all decresed, indicating a need for caution in a long term use of high concentrations. Mitochondrial hypofunction, manifested by the decrease of OTC activity, probably interferes 
with the therapeutic effect on hyperammonemia. Although no remarkable morphological or functional disturbance was noted after $24 \mathrm{hr}$, DNA synthesis was markedly inhibited even at the relatively low concentration of $100 \mu \mathrm{g} / \mathrm{ml}$. Even a low dose of BA-Na may with chronic administration suppress the liver function in patients with congenital hyperammonemia.

Since this study is an in vitro experiment using rat liver, the results cannot be directly compared with the changes of human liver in vivo. These results suggest, hewever, that even BA-Na concentrations currently assumed to be safe may cause some damage to the liver cells, calling for a careful reevaluation of the dose of BA-Na to be employed.

\section{References}

1) Batshaw, M.L., Thomas, G.H. \& Brusilow, S.W. (1981) New approaches to the diagnosis and treatment of inborn errors of urea synthesis. Pediatrics, 68, 290-297.

2) Gatley, S.J. \& Sherratt, H.S.A. (1977) The synthesis of hippurate from benzoate and glycine by rat liver mitochondria. Submitochondrial localization and kinetics. Biochem. J., 166, 39-47.

3) Granner, D.K. \& Tomkins, G.M. (1970) Tyrosine aminotransferase (rat liver). Meth. Enzymol., 17A, 633-637.

4) Green, T.P. (1981) Sodium benzoate in the treatment of hyperammonemia in newborn. Pediat. Res., 15, 630.

5) Schimke, R.T. (1962) Adaptive characteristics of urea cycle enzymes in the rat. $J$. biol. Chem., 237, 459-468.

6) Tanaka, K., Sato, M., Tomita, Y. \& Ichihara, A. (1978) Biochemical studies on liver functions in primary cultured hepatocytes of adult rat. J. Biochem., 84, 937-946. 